Urszula Nowicka

Wydział Prawa Kanonicznego UKSW

\title{
Stwierdzenie stanu wolnego wiernych Kościoła Ewangelicko-Augsburskiego w Polsce przed zawarciem małżeństwa w Kościele katolickim
}

Stwierdzenie stanu wolnego przed zawarciem małżeństwa w Kościele katolickim polega - w sensie najbardziej właściwym - na wykluczeniu istnienia przeszkody węzła małżeńskiego, która - z samego prawa Bożego - czyni małżeństwo nieważnym. Jeśli nupturienci zgłaszający się do kancelarii parafialnej są oboje wyznania katolickiego, wówczas trudności w tym względzie można uznać za minimalne. Sytuacja zmienia się natomiast wówczas, gdy zawierane małżeństwo ma być małżeństwem mieszanym, a tym bardziej, jeśli strona niekatolicka w takim związku miała już wcześniej zawarte inne małżeństwo. Uznanie naturalnego prawa osoby do zawarcia małżeństwa oraz respektowanie praw innych Kościołów i wspólnot chrześcijańskich sugeruje bowiem pytanie o stosunek Kościoła katolickiego do takich małżeństw oraz do rozwodów, które są przewidziane w większości ustawodawstw niekatolickich. Jak zatem powinien postępować duszpasterz katolicki, stając wobec tak trudnych i wątpliwych kwestii prawnych? 


\section{Koncepcja małżeństwa w Kościele Ewangelicko-Augsburskim}

\subsection{Pojęcie małżeństwa}

W $₫ 107$ Pragmatyki służbowej ${ }^{1}$ zostało zapisane, że „istotnymi przymiotami małżeństwa są: jedność i nierozerwalność, które w małżeństwie chrześcijańskim nabierają szczególnej mocy z racji Bożego ustanowienia i autorytetu". Luterańska definicja małżeństwa pojmuje małżeństwo jako „darowaną przez Boga człowiekowi możliwość życia mężczyzny i kobiety", nie ma tu natomiast mowy o sakramentalności małżeństwa. Małżeństwo wedle koncepcji protestanckiej nie jest bowiem sakramentem. Sakrament, zgodnie z definicją ewangelicką, jest „świętą czynnością (obrządkiem) ustanowionym przez Jezusa Chrystusa, w której pod widzialnymi znakami człowiek otrzymuje niewidzialną łaskę Bożą" ${ }^{2}$. Małżeństwo - wedle tej koncepcji - nie spełnia zatem podstawowych kryteriów sakramentu: przede wszystkim istnieje od początku ludzkości, a nie zostało ustanowione jakimś wyraźnym słowem przez Chrystusa oraz pozbawione jest charakteru zbawczego ${ }^{3}$. W małżeństwie uwydatnia się jego charakter naturalny ${ }^{4}$, nie sakramentalny. Gdyby tak było, jak tłumaczą ewangelicy, wówczas byłoby ono przeznaczone wyłącznie dla chrześcijan, skoro tylko oni mogą brać udział w udzielaniu środków łaski ${ }^{5}$. Tymczasem ma ono

1 Pragmatyka służbowa jest dokumentem ustalającym porządek prawny Kościoła Ewangelicko-Augsburskiego w Rzeczypospolitej, zatwierdzonym w 2011 r. przez Synod tegoż Kościoła.

2 A. JAGUCKi, Pytania wiary. „Mały katechizm” ks. Marcina Lutra w pytaniach i odpowiedziach, Bielsko-Biała 1998, s. 101.

3 Aa.Vv., Porównanie wyznań rzymskokatolickiego, prawosławnego, ewangelicko-augsburskiego, ewangelicko-reformowanego, Warszawa 2002, s. 98; P. KopIEC, Instytucja małżeństwa a sakramentologia luterańska, Roczniki Teologiczne 55 (2008), z. 7, s. 174-175.

4 J. Podzielny, Wizja małżeństwa w świetle ewangelickiej etyki teologicznej, Opole 2011, s. 207.

5 Por. M. WICHARY, Czy protestanci uważaja małżeństwo za sakrament?, https:// proteologia.com/2009/04/08/czy-protestanci-uwazaja-malzenstwo-za-sakrament/ (data dostępu: 15 września 2016 r.). 
charakter uniwersalny, występuje w każdej kulturze, na całym świecie, także poza obrębem religii chrześcijańskiej, w społeczeństwach pogańskich i zeświecczonych obszarach życia ${ }^{6}$. Luteranie - jak twierdzą - nie odnajdują potwierdzenia sakramentalności małżeństwa w Piśmie Świętym. Wedle ich opinii małżeństwo stanowi jedynie ziemskie powołanie człowieka, jego cel ma wyłącznie przyrodzony i doczesny charakter?

Nie zmienia to jednak faktu, że małżeństwo posiada szczególną wartość i że dla chrześcijan zyskuje nowy wymiar. Chociaż jest „środkiem powszechnej łaski”, czyli skierowanej do wszystkich ludzi, bez powiązania ze zbawieniem przez Jezusa Chrystusa, to jednak małżeństwo chrześcijańskie stanowi również obraz miłości Chrystusa do Jego Kościoła, jest źródłem błogosławieństwa i więzią w szczególny sposób otoczoną opieką przez Boga ${ }^{8}$. W nim bowiem, poprzez związek z Chrystusem, dokonuje się szczególne dzieło uświęcenia tego stanu9. W Pragmatyce służbowej małżeństwo zostało nazwane „przymierzem dwojga osób, mężczyzny i kobiety” (por. \$ 107), które jest najlepszym określeniem jego misterium ${ }^{10}$.

\subsection{Nierozerwalność małżeństwa}

O nierozerwalności, względem małżeństwa, wprost wspomina się w Pragmatyce służbowej trzy razy. Najpierw w cytowanym już $\$ 107$ nr 1 zostało zapisane, że ,istotnymi przymiotami małżeństwa są: jedność i nierozerwalność, które w małżeństwie chrześcijańskim nabierają szczególnej mocy z racji Bożego ustanowienia i autorytetu”.

\footnotetext{
6 Por. J. Podzielny, Wizja małżeństwa..., dz. cyt., s. 150.

7 Małżeństwo i rodzina w nauczaniu Kościoła ewangelicko-augsburskiego, http:// model-rodziny.eprace.edu.pl/953,Malzenstwo_i_rodzina_w_nauczaniu_Kosciola_ ewangelicko-augsburskiego.html (data dostępu: 15 września 2016 r.).

8 Por. M. WiChary, Czy protestanci uważaja małżeństwo za sakrament?, art. cyt.

9 J. Podzielny, Wizja małżéstwa..., dz. cyt., s. 151.

10 B. Fober, Nierozerwalność małżeństwa $w$ luterańskim porzadku prawnym ze szczególnym uwzględnieniem prawodawstwa Kościoła Ewangelicko-Augsburskiego w Rzeczpospolitej Polskiej, Annales Canonici 8 (2012), s. 157.
} 
Na dowód takiego sformułowania przywołano w tym miejscu liczne perykopy biblijne: o stworzeniu człowieka (1 Mż 1,27-28); o ukształtowaniu kobiety z żebra mężczyzny i byciu przez nich jednym ciałem (1 Mż 2,18-24); o dialogu Jezusa $\mathrm{z}$ faryzeuszami i uczniami na temat możliwości oddalenia żony (Mt 19,3-8; Mk 10,6-9.11.12); o pouczeniu św. Pawła na temat nieoddalania żony (1 Kor 7,10-11); o małżeństwie jako wielkiej tajemnicy (Ef 5,22-33); o wzajemnej relacji pomiędzy mężem a żoną (Kol 3,12-19.23.24; 1 P 3,1-7). Warto zwrócić uwagę, że również Kościół katolicki, uzasadniając nierozerwalność małżeństwa, odwołuje się do tych samych słów i opisów biblijnych. Następnie w $\$ 110$ wskazano, że „podstawowym prawem i obowiązkiem małżonków jest życie w miłości, wierności, jedności i nierozerwalności oraz tworzenie rodziny i wychowanie dzieci w wierze i wierności Kościołowi”. W końcu w $\$ 145$ zostało podkreślone, że „Kościół Ewangelicko-Augsburski stoi na biblijnym stanowisku nierozerwalności małżeństwa”. Podstawą nierozerwalności małżeństwa jest zatem przede wszystkim Pismo Święte, w którym małżeństwo, jako powołana przez Pana Boga wspólnota życia mężczyzny i kobiety, ze swej natury domaga się wyłączności i nierozerwalności. Ten Boży zamysł małżonkowie mogą wypełnić dzięki Chrystusowi i darowi Jego miłości, przez co małżeństwo nie może podlegać wyłącznie ludzkim decyzjom, wyborom, czy to samych małżonków, społeczeństwa czy państwa $^{11}$. Tym niemniej koncepcja nierozerwalności małżeństwa w Kościele Ewangelicko-Augsburskim znacznie odbiega od jej rozumienia w Kościele katolickim, z uwagi na możliwość rozwiązania małżeństwa, o którym będzie mowa poniżej.

\section{Czy Kościół katolicki uznaje małżeństwa zawarte przez wiernych Kościoła Ewangelicko-Augsburskiego za ważne?}

Prawo do zawarcia małżeństwa jest naturalnym prawem każdego człowieka. Nie tylko katolika, czy osoby ochrzczonej, ale każdego, niezależnie od wyznawanej przez niego wiary, pochodzenia, narodu,

11 Por. J. Podzielny, Wizja matżeństwa..., dz. cyt., s. 157-158. 
języka czy koloru skóry. Wszystkie małżeństwa, niezależnie od tego kiedy i przez kogo są zawierane, podlegają prawu Bożemu, jako niezbywalnemu i jednemu dla wszystkich. Ta zasada pozostaje niezmienna, i niezależnie od tego, czy poszczególne normy tego prawa Bożego zostały ujęte w przepisy prawne, one obowiązują zarówno katolików, jak również wiernych innych wyznań czy nawet osoby nieochrzczone. Małżeństwo katolików (choćby tylko jedna strona była katolicka) podlega ponadto prawu kanonicznemu (por. kan. $1059 \mathrm{KPK}$; art. $2 \$ 1 \mathrm{DC}$ ), w którym mogą być ustanawiane również warunki formalne, od zachowania których zależy skuteczność dokonywanych aktów prawnych. Do takich warunków należy konieczność zawarcia małżeństwa w formie kanonicznej, której zachowania prawo kanoniczne nie może jednak nakazać osobom nie należącym do Kościoła katolickiego, ani tym bardziej nie może uzależniać od niej ważności ich małżeństwa.

Nie oznacza to jednak, że prawodawca kościelny pozostał obojętny na formę, w której zawierają małżeństwa osoby mu nie podlegające. Innymi słowy, nie zignorował faktu, że zawierają małżeństwo czyniąc zadość wymogom prawa, które ich obowiązuje. Byłoby wręcz zniewagą wobec wspólnot kościelnych akatolickich uznawanie za nieważne ich małżeństw z powodu braku formy. Dlatego w art. $4 \$ 1$ nr 2 instrukcji procesowej Dignitas connubii została ustanowiona zasada, zgodnie z którą „ilekroć sędzia kościelny winien rozpatrywać nieważność małżeństwa akatolików ochrzczonych: (...) w tym, co dotyczy formy zawarcia małżeństwa, Kościół uznaje każdą formę przepisaną lub dopuszczoną przez prawo w Kościele lub Wspólnocie kościelnej, do której należały strony w czasie zawierania małżeństwa (...)”. Oznacza to, że ilekroć wierni należący do Kościoła Ewangelicko-Augsbuskiego zawierają małżeństwo w formie, której wymaga od nich prawo, którym są związani, wówczas Kościół katolicki uznaje takie małżeństwa za ważne.

W \$ 122 Pragmatyki Służbowej zostało zapisane, że „małżeństwo zawiera się przed Bogiem, w obecności ordynowanego duchownego Kościoła Ewangelicko-Augsburskiego oraz dwóch świadków”, którzy - zgodnie z $\$ 123$ - „powinni być pełnoletni, wierzący, świadomi 
istoty dokonującego się aktu”. Wynikałoby z tego w pierwszej kolejności, że Kościół Ewangelicko-Augsburski w Rzeczypospolitej nie uznaje (nie adoptuje) cywilnego systemu małżeńskiego w tym sensie, że nie uznaje małżeństw zawartych w formie cywilnej ${ }^{12}$, ale ustanawia własną formę zawarcia małżeństwa, do której zachowania zobowiązuje swoich wiernych. Tym samym również Kościół katolicki, będąc zobligowany do oceny ważności małżeństw zawieranych przez tych wiernych, nie może uznać za ważne tych zawartych jedynie przed urzędnikiem stanu cywilnego, ale i nie może zignorować faktu zawarcia małżeństwa przed duchownym Kościoła Ewangelicko-Augsburskiego. W konsekwencji kontrakt jedynie cywilny tych wiernych nie stanowi przeszkody do zawarcia małżeństwa w Kościele katolickim, zaś małżeństwo zawarte przez nich w Kościele, do którego należą i z zachowaniem prawa tego Kościoła - zawsze.

12 Tak przynajmniej wynika z treści analizowanego $\$ 122$ Pragmatyki służbowej, który - poza zawarciem małżeństwa w kościele - nie przewiduje innej, równoważnej czy choćby tolerowanej tylko formy zawarcia. Natomiast w cytowanym już dokumencie „Małżeństwo i rodzina w nauczaniu Kościoła ewangelicko-augsburskiego” zostało zapisane: „Jako instytucja społeczna, podobna wielu innym niezbędnym do życia człowieka instytucjom, małżeństwo podlega wyłącznie ustawodawstwu świeckiemu, i to zarówno w sferze jego powstawania, jak też norm rządzących jego funkcjonowaniem. (...) I chociaż zawarcie małżeństwa dokonuje się zawsze w kościele, to ceremonia ta ma jedynie charakter wezwania do Boga o pobłogosławienie nowożeńców i prośby skierowane do wiernych o modlitwę w ich intencji. Poza tym jest to dogodna okazja przedstawienia wspólnocie wiernych wierzących nowego związku.

Mimo, że małżeństwo w Kościele luterańskim nie jest sakramentem, jest bardzo cenione. Z punktu widzenia wyznania luterańskiego każda forma zawarcia związku małżeńskiego jest ważna, tym bardziej, że władza świecka jest przez luteranów uznawana za tak samo ważna, jak władza duchowna. Dlatego ślub cywilny, nawet nie potwierdzony uroczystością kościelną, uznawany jest za prawomocny. Sama ceremonia, związana z zawarciem małżeństwa nie stanowi o jakości małżeństwa. Warto tu dodać, że Luter sam przekazał ustawodawstwu cywilnemu pełną kompetencję w odniesieniu do spraw małżeńskich, pozostawiając Kościołowi jedynie sprawę pobłogosławienia związku i domagając się od niego modlitwy za nowożeńców”. 


\section{Możliwość rozwiązania małżeństwa w Kościele Ewangelicko-Augsburskim}

Nierozerwalność małżeństwa, uznawana i podkreślana w prawodawstwie Kościoła Ewangelicko-Augsburskiego, doświadcza jednak pewnego ,ale”, zawartego w $\$ 145$ Pragmatyki służbowej. Trudno dywagować, czy owo „ale” wolno uznać za wyjątek od zasady, czy raczej należałoby uważać go za samą zasadę akceptowaną przez Kościół $\mathrm{z}$ uwagi na pewne szczególne okoliczności. Faktem jest natomiast, że Kościół Ewangelicko-Augsburski, broniąc nierozerwalności małżeństwa, podkreśla również, że „nie przeprowadza postępowania rozwodowego”. Jakkolwiek słowa te chciałoby się przyjąć za „dobrą monetę", to jednak okazuje się, że z faktu, iż Kościół sam postępowania rozwodowego nie prowadzi, nie wynika jeszcze, że rozwodu jako takiego nie uznaje. W analizowanym $\$ 145$ Pragmatyki służbowej zostało bowiem zapisane: „Tam jednak, gdzie małżeństwo uległo rozpadowi i zostało rozwiedzione wyrokiem Sądu, przyjmuje do wiadomości istniejący stan rzeczy jako wynik ludzkiego grzechu i zatwardziałości serc".

Można się zastanawiać, w jaki sposób pogodzić nierozerwalność małżeństwa $z$ uznaniem faktu jego rozpadu. I o ile w tym przypadku możliwe byłoby jeszcze tłumaczenie rozgraniczeniem pomiędzy stanem faktycznym (małżonkowie rozstali się) a stanem prawnym (czyli istniejącym niezależnie od tego rozstania małżeństwem), o tyle treść $\$ 147$ Pragmatyki stużbowej zdaje się burzyć również tę próbę interpretacji. Czytamy w nim bowiem o tym, że „osoba rozwiedziona, pragnąca wstąpić w nowy związek małżeński, zobowiązana jest uzyskać dyspensę Biskupa Kościoła Ewangelicko-Augsburskiego, który zajmie stanowisko po zaopiniowaniu wniosku przez właściwego Proboszcza". Innymi słowy, dowiadujemy się nie tylko o tym, że Kościół Ewangelicko-Augsburski „przyjmuje do wiadomości” fakt rozpadu małżeństwa, ale że uwzględniając ten fakt zezwala na zawarcie kolejnego małżeństwa w Kościele. Dokonuje tego poprzez udzielanie dyspensy od prawa Bożego, z którego wynika nierozerwalność małżeństwa. 


\section{Czy Kościół katolicki może uznać rozwody akceptowane w Kościele Ewangelicko-Augsburskim?}

Powyższa możliwość, przewidziana prawnie, prowokuje natychmiast pytanie, czy skoro Kościół katolicki uznaje małżeństwo zawierane przez wiernych Kościoła Ewangelicko-Augsburskiego, zgodnie z wymaganiami tegoż Kościoła, to czy jednocześnie akceptuje (lub czy powinien akceptować) fakt rozwodów, również przecież prawnie przewidzianych.

\subsection{Niewystarczalność dokumentów stwierdzających stan wolny luteran}

W kan. 1066 KPK prawodawca kościelny postanowił, że „przed zawarciem małżeństwa należy się upewnić, że nic nie stoi na przeszkodzie do jego ważnego i godziwego zawarcia”, polecając jednocześnie, aby Konferencje Episkopatów poszczególnych krajów wydały normy dotyczące m.in. „odpowiednich środków do przeprowadzenia badań przed zawarciem małżeństwa" (kan. 1067 KPK). Podstawowym dokumentem, w którym powinien zostać potwierdzony stan wolny nupturientów, jest metryka chrztu, co zostało podkreślone również przez Konferencję Episkopatu Polski, w Instrukcji dotyczącej przygotowania do zawarcia małżeństwa w Kościele katolickim ${ }^{13}$. W niej bowiem winna zostać zawarta adnotacja o zawieraniu bądź niezawieraniu wcześniej związku małżeńskiego. Wydaje się, że w sytuacji małżeństwa zawieranego przez katolików metryka ta usuwa wszelkie wątpliwości w omawianej kwestii (o ile oczywiście wszyscy proboszczowie dopełnili w należyty sposób swoich obowiązków związanych z dokonywaniem wpisów w księgach ochrzczonych). Trudność może się natomiast pojawić w małżeństwach zawieranych ze stroną niekatolicką. Zwróciła na to uwagę Konferencja Episkopatu Polski,

\footnotetext{
13 Konferencja Episkopatu Polski, Instrukcja o przygotowaniu do zawarcia małżeństwa w Kościele katolickim, 13 II 1989, w: Cz. Krakowiak, L. Adamowicz (opr.), Dokumenty duszpastersko-liturgiczne Episkopatu Polski (1966-1993, Lublin 1994, s. 206, n. 98.
} 
podkreślając, iż „takich spraw nie da się załatwić schematycznie”"14. Dotyczy to również małżeństw wiernych należących do Kościoła Ewangelicko-Augsburskiego.

W pierwszej bowiem kolejności należy zwrócić uwagę na treść adnotacji widniejącej w dokumencie przedstawianym przez niekatolików, zwłaszcza, jeśli wcześniej mieli oni już zawarte małżeństwo. $Z$ uwagi na możliwość rozwiązania małżeństwa, o której była mowa powyżej, należy z mocą podkreślić, iż nie są wystarczające adnotacje potwierdzające, iż „nie ma przeszkód na zawarcie związku małżeńskiego” bądź że „strony są stanu wolnego”. Skoro bowiem ich stan wolny lub brak przeszkód może być wynikiem rozwodu udzielonego przez sąd cywilny i zaakceptowanego przez Kościół Ewangelicko-Augsburski, to faktu tego nie można uznać za wystarczający dla możliwości dopuszczenia do zawarcia małżeństwa w Kościele katolickim. Tym bardziej za niewystarczające należy uważać wszelkie dokumenty potwierdzające wprost istnienie wcześniejszego związku małżeńskiego, który został następnie rozwiązany zgodnie z prawem ewangelicko-augsburskim.

20 października 2006 r. Najwyższy Trybunał Sygnatury Apostolskiej wydał deklarację, w której poruszona została kwestia niewystarczalności dokumentów mających na celu potwierdzenie stanu wolnego nupturientów ${ }^{15}$. Deklaracja ta odnosi się wprawdzie do Kościoła prawosławnego w Rumunii, tym niemniej wydaje się, że - co do istoty - wolno jej treść stosować przez analogię również w przypadkach zawierania małżeństw $\mathrm{z}$ wiernymi innych Kościołów chrześcijańskich

Otóż z deklaracji tej wynika, iż przyjmując za punkt wyjścia ważność małżeństw zawieranych z zachowaniem praw, którym podlegają nupturienci, należy przyjąć istnienie przeszkody węzła małżeńskiego wynikającego $\mathrm{z}$ zawarcia takich małżeństw. $Z$ tego powodu wszelkie dokumenty o stanie wolnym nie mogą być wystarczające na forum

\footnotetext{
14 Por. tamże, s. 181, nr 57.

15 Supremum Signaturae Apostolicae Tribunal, „Declaratio” sull'ammissione dei fedeli della Chiesa ortodossa romena alla celebrazione di un nuovo matrimonio nella Chiesa cattolica, 20 X 2006, Prot. N. 37577/05 VAR, Communicationes 39 (2007), n. 1, s. 66-67; Ius Ecclesiae 19 (2007), n. 3, s. 773.
} 
Kościoła katolickiego, ponieważ uwzględniają one niekatolicką praktykę dopuszczania do zawarcia kolejnego małżeństwa w Kościele ${ }^{16}$. A stosowanie owej akatolickiej dyscypliny przeciwnej nierozerwalności małżeństwa oraz opartym na tej dyscyplinie wyrokom i decyzjom, jest niedopuszczalne ${ }^{17}$.W konsekwencji stan wolny nupturientów, o których mowa, wolno stwierdzać wyłącznie w oparciu o prawomocny wyrok katolickiego sądu kościelnego, wydany na drodze zwyczajnego procesu sądowego i z zachowaniem norm, które go dotyczą, względnie decyzję papieską o udzieleniu dyspensy od małżeństwa ważnie zawartego, ale niedopełnionego ${ }^{18}$.

\subsection{Konieczność procesu w trybunale Kościoła katolickiego}

Z powyższego wynika, że jeśli strona niekatolicka, pragnąca zawrzeć małżeństwo w Kościele katolickim, już wcześnie pozostawała w innym związku religijnym, zawartym w swoim Kościele, a następnie rozwiązanym, jej stan wolny musi być stwierdzony na drodze procesu sądowego (względnie uzyskany poprzez dyspensę papieską super rato). Po to, aby nie dopuścić do zawarcia kolejnego, bigamicznego małżeństwa, co sprzeciwia się zasadzie nierozerwalności małżeństwa. Dopiero w przypadku wyroku afirmatywnego, czyli stwierdzającego nieważność zawartego uprzednio małżeństwa, wolno wszcząć przygotowanie do zawarcia małżeństwa w Kościele katolickim. Aktualne

\footnotetext{
16 Por. P. BIANCHI, Dichiarazioni di stato libero rilasciate da autorità ecclesiali ortodosse. Una recente dichiarazione del Supremo Tribunale della Segnatura Apostolica, Quaderni di diritto ecclesiale 21 (2008), s. 262.

17 Por. A. Stankiewicz, Komentarz do art. 4, w: T. Rozkrut (red.), Komentarz do Instrukcji procesowej „Dignitas connubii”, Sandomierz 2007, s. 30.

18 "Quapropter pars orthodoxa, quae eiusmodi documento munita novum matrimonium inire intendit in Ecclesia catholica, non consideratur libera, quousque nullitas praecedentis eius matrimonii declarata non fuerit a Tribunali ecclesiastico catholico per decisionem exsecutivam vel idem matrimonium, si adsint necessariae condiciones, a Romano Pontifice solutum fuerit ob inconsummationem" - SUpremum Signaturae Apostolicae Tribunal, „Declaratio” sull'ammissione dei fedeli..., dok. cyt., s. 67.
} 
pozostaje jednak pytanie, jakie prawo powinien wówczas stosować sędzia katolicki, jeśli ma zbadać kwestię małżeństwa tych, którzy prawu katolickiemu nie podlegają.

\subsubsection{Jakie normy proceduralne powinien stosować sędzia katolicki?}

W pierwszej kolejności pytanie to będzie dotyczyło stosowanej procedury. A konkretnie należy zadać pytanie, do którego trybunału powinien zgłosić się akatolik pragnący stwierdzić nieważność swojego małżeństwa oraz wedle jakich norm powinien postępować sędzia kościelny, kiedy przyjmie sprawę do rozstrzygnięcia. Wszak akatolików, a zatem również wiernych Kościoła Ewangelicko-Augsburskiego, nie obowiązują przepisy zawarte w Kodeksie Prawa Kanonicznego, ani w żadnych innych dokumentach prawnych Kościoła katolickiego ${ }^{19}$. $\mathrm{Z}$ tego punktu widzenia należałoby powiedzieć, że akatolik ma pełną wolność w wyborze trybunału, do którego chce zwrócić się o orzeczenie nieważności swojego małżeństwa. Jednakże z faktu, że akatolicy - jako tacy - nie podlegają przepisom prawa katolickiego, nie wynika, że jeśli sędzia musi orzekać o nieważności ich małżeństw, to nie musi stosować norm prawnych Kościoła katolickiego, do którego sam należy.

Potwierdzenie tego stanowiska znajdujemy w deklaracji Sygnatury Apostolskiej z 28 maja 1993 r., stanowiącej jednocześnie odpowiedź na pytanie postawione jej przez jednego $\mathrm{z}$ Wikariuszy sądowych o jurysdykcję Kościoła nad małżeństwem akatolików oraz - w przypadku odpowiedzi pozytywnej - o konieczność lub nie procesu sądowego w takich przypadkach. W deklaracji Sygnatury Apostolskiej czytamy: in casu adhibendus est processus iudicialis ad normam cann.

\footnotetext{
19 Wynika to z kan. 1 KPK, na mocy którego jego kanony odnoszą się do Kościoła łacińskiego oraz z kan. 11 KPK, który czyni zobowiązanymi do zachowania ustaw czysto kościelnych jedynie tych, którzy zostali ochrzczeni w Kościele katolickim lub do niego przyjęci (z zastrzeżeniem, obok owego kryterium eklezjologicznego, również psychologicznego (używanie rozumu) oraz chronologicznego (ukończenie siódmego roku życia)).
} 
1671-1691 ${ }^{20}$. Oznacza to, że w sytuacji, gdy o rozstrzygnięcie kwestii ewentualnej nieważności małżeństwa proszą - w naszym przypadku wierni Kościoła Ewangelicko-Augsburskiego, wówczas sędzia zobowiązany jest do przestrzegania i stosowania norm regulujących proces specjalny, dotyczący spraw o orzeczenie nieważności małżeństwa. Czyli - innymi słowy - w tym, co dotyczy norm czysto proceduralnych, sędzia związany jest kanonami Kodeksu, któremu sam podlega. W obecnym stanie prawnym, uwzględniając fakt przeprowadzonej niedawno przez papieża Franciszka reformy, należy uaktualnić treść przedmiotowej deklaracji, co jednak nie zmienia jej istoty.

\subsubsection{Wedle jakich norm merytorycznych powinien orzekać sędzia katolicki?}

Wykonując swoją władzę sądzenia sędzia katolicki powinien zatem kierować się normami regulującymi procedurę zwyczajnego procesu. Niemal natychmiast pojawia się jednak pytanie, jakie prawo musi wówczas brać pod uwagę? Wszak nie może rozstrzygać o nieważności małżeństw akatolików na podstawie prawa, któremu oni nie podlegają. Cóż zatem powinien czynić?

Żadnej wątpliwości nie budzi sytuacja, w której przyczyną potencjalnej nieważności małżeństwa jest wada konsensu oparta na prawie naturalnym lub przeszkoda mająca swoje źródło w prawie Bożym pozytywnym lub naturalnym. Takiemu prawu podlegają bowiem wszyscy, także niekatolicy, ochrzczeni i nieochrzczeni. Podlegają mu zatem również wierni Kościoła Ewangelicko-Augsburskiego. Prawo Boże jest bowiem niezbywalne i jest jedno dla wszystkich. Jednak oprócz prawa Bożego istnieje także prawo kościelne ${ }^{21}$, któremu -

\footnotetext{
20 Supremum Signaturae Apostolicae Tribunal, Dichiarazione sulla giurisdizione della Chiesa riguardo al matrimonio celebrato tra due acattolici, $28 \mathrm{~V} 1993$, Prot. N. 23805/92 VT, Ius Ecclesiae 6 (1994), nr 1, s. 366, n. 1.

21 Por. U. Nowicka, Prawosławne wyroki rozwodowe i ich skutki na forum Kościoła katolickiego, Prawo i Kościół 2 (2010), s. 116; U. Now IckA, Aplikacja prawa przy zawieraniu małżeństw $z$ akatolikami według legislacji łacińskiej $i$ wschodniej, w: J. Wroceński, J. KrajCZyński (red.), Finis legis Christus. Księga pamiątkowa
} 
zgodnie z kan. $11 \mathrm{KPK}$ - podlegają jedynie ochrzczeni w Kościele katolickim lub do niego przyjęci. Dlatego jest oczywiste, iż nie można wyrokować o małżeństwie akatolików aplikując do nich to prawo, które $\mathrm{z}$ woli ustawodawcy kościelnego (katolickiego) uniezdalnia pewne osoby do zawarcia małżeństwa lub postanawia, że podjęty przez nie akt jest nieważny. Zatem według jakich kryteriów ma orzekać sędzia kościelny w omawianym przypadku?

\subsubsection{Luka prawna w KPK}

Niestety, w KPK brakuje bezpośredniej dyspozycji w tym względzie. Prawodawca stanowi, że małżeństwo katolików podlega prawu Bożemu oraz prawu kanonicznemu, z zachowaniem kompetencji władzy państwowej w tym, co dotyczy czysto cywilnych skutków małżeństwa (KPK, kan. 1059 KKKW, kan. $780 \$ 1$ ) i dodaje „choćby tylko jedna strona była katolicka”. Nie określa natomiast, jakie prawo należy stosować, gdy rozpatruje się sprawy małżeńskie akatolików. Owszem, ten brak mógłby sugerować, że w związku z tym należy uwzględnić i stosować jedynie prawo Boże; wydaje się jednak, że taka aplikacja prowadziłaby w niektórych przypadkach do absurdalnych skutków praktycznych ${ }^{22}$. Ale skoro musi zostać odrzucona, to w ten sposób w legislacji łacińskiej powstaje ogromna luka prawna.

Błędem byłoby jednak sądzić, iż kwestia ta została przez kodyfikatorów zapomniana, przeoczona czy też celowo zignorowana. W okresie przygotowywania nowego Kodeksu wielkiej sławy kanonista Urbano Navarrete podkreślał: si in futurum statueretur principium contrarium, scilicet acatholicos non teneri legibus ab Ecclesia catholica latis nisi expresse declaretur, creabitur immensa lacuna legis ${ }^{23}$. Kodyfikatorzy

dedykowana Księdzu Profesorowi Wojciechowi Góralskiemu z okazji siedemdziesiątej rocznicy urodzin, Warszawa 2009, s. 642.

22 Por. U. NowickA, Stwierdzenie stanu wolnego wiernych prawosławnych na forum Kościoła katolickiego, Warszawa 2012, s. 305.

23 Por. U. Navarrete, Competentia Ecclesiae in matrimonium baptizatorum eiusque limites, Periodica 67 (1978), s. 101. 
dostrzegali ten brak, stąd pojawiła się nawet propozycja normy, zgodnie z którą należałoby uznać, iż małżeństwo akatolików regulowane jest prawem Bożym oraz religijnym lub cywilnym, obowiązującym we wspólnocie, do której oni należą ${ }^{24}$. Niestety, została odrzucona, uznano ją bowiem za zbyteczną, niebezpieczną i antyekumeniczną; co więcej, obawiano się, że byłaby, w jej wyniku, uznana kompetencja innych Wspólnot kościelnych odnośnie do małżeństwa ${ }^{25}$.

\subsubsection{Normy KKKW i instrukcji Dignitas connubii}

Lata doświadczeń i refleksji w tym względzie spowodowały jednak, że kwestia nie została zapomniana. Uwzględnili ją najpierw kodyfikatorzy Kodeksu wschodniego (por. kan. $781 \mathrm{KKKW),} \mathrm{a} \mathrm{kilkanaście}$ lat później także autorzy instrukcji procesowej Dignitas connubii. Jej art. $4 \$ 1$ jest dosłownym powtórzeniem treści kan. $781 \mathrm{KKKW}$, który dla potrzeb niniejszego opracowania należy odczytać w sposób następujący: „ilekroć sędzia kościelny winien rozpatrywać nieważność małżeństwa akatolików ochrzczonych: $1^{\circ} \mathrm{w}$ tym, co dotyczy prawa, którym strony były związane w czasie zawierania małżeństwa, należy zachować art. $2 \$ 2$, a zatem sędzia powinien wziąć pod uwagę: prawo własne Kościoła lub Wspólnoty kościelnej, do której należy stron akatolicka, jeśli ta Wspólnota posiada własne prawo małżeńskie (art. $2 \$ 2 \mathrm{n} .1$ ) lub prawo, które obowiązuje stronę akatolicką, jeśli Wspólnota kościelna, do której należy, nie ma własnego praw małżeńskiego (art. $2 \$ 2$ n. 2); $2^{\circ}$ w tym, co dotyczy formy zawarcia małżeństwa, Kościół uznaje każdą formę przepisaną lub dopuszczoną przez prawo w Kościele lub Wspólnocie kościelnej, do której należały strony w czasie zawierania małżeństwa, byleby tylko małżeństwo było

\footnotetext{
24 "Matrimonium eorum qui extra Ecclesiam catholicam baptizati sunt, nec in eam recepti, regitur iure divino et iure religioso vel civili, quo regitur (matrimonium) in coetu christiano ad quem quisque pertinetę. - Communicationes 9 (1977), nr 1, s. 127.

25 "Nisi ad exigentiam quandam systematicam, quia de facto acatholicorum nihil interest de nostra lege, imo haec lex male acciperetur ab oecumenistis". - Tamże.
} 
zawarte z zachowaniem świętego obrzędu, jeśli przynajmniej jedna strona należała do jakiegoś Kościoła wschodniego akatolickiego".

Stąd w przypadku zaskarżenia małżeństwa $\mathrm{z}$ tytułu przeszkody zrywającej lub wady zgody małżeńskiej, pochodzących z prawa kościelnego, sędzia będzie zobowiązywany stosować prawo, któremu w chwili zawierania małżeństwa strona akatolicka podlegała. W tym, co dotyczy wiernych Kościoła Ewangelicko-Augsburskiego należy zatem uwzględnić prawo cywilne, któremu podlegali nupturienci w momencie zawierania małżeństwa (ich małżeństwo podlega bowiem ustawodawstwu świeckiemu, i to zarówno w sferze jego powstawania, jak też norm rządzących jego funkcjonowaniem ${ }^{26}$ ), względnie wymogi sformułowane w artykułach wyżej wskazanej Pragmatyki służbowej. W ten sposób dokonuje się zwykłej akceptacji formalnej dyscypliny, której rzeczywiście podlegali akatolicy w chwili zawierania małżeństwa, $\mathrm{z}$ racji prawnych i duszpasterskich, dla uniknięcia ewentualnych konfliktów prawa ${ }^{27}$. Kościół katolicki bierze pod uwagę takie normy i stosuje, nie przyjmując ich absolutnie za swoje własne. Te prawa, o ile nie sprzeciwiają się prawu Bożemu, należy uwzględnić i aplikować, ilekroć zachodzi konieczność rozpatrzenia nieważności małżeństwa akatolików ochrzczonych. I a contrario, nie można oceniać małżeństw niekatolików na podstawie ustaw prawa pozytywnego Kościoła katolickiego, któremu oni nie podlegają i którego nie mają obowiązku przestrzegać.

\section{Zakończenie}

Zaprezentowana powyżej próba wyjaśnienia trudnych i wątpliwych kwestii dotyczących małżeństw zawartych przez wiernych Kościoła Ewangelicko-Augsburskiego w Polsce, a następnie rozwiązanych zgodnie z prawem tegoż Kościoła, skłania do sformułowania

\footnotetext{
${ }^{26}$ Małżeństwo i rodzina w nauczaniu Kościoła ewangelicko-augsburskiego, dok. cyt.

27 M. F. Pompedda, Commento ai cann. 780-781, w: P. V. Pinto (red.), Commento al Codice dei Canoni delle Chiese orientali, Libreria Editrice Vaticana 2001, s. 655.
} 
kilku istotnych wniosków. Ich aplikacja wydaje się konieczna, aby można było ze spokojnym sumieniem i legalnie dopuszczać luteran do zawierania małżeństw w Kościele katolickim. Pierwszym zaś tego kryterium jest konieczność zwrócenia szczególnej uwagi tych, którym została powierzona troska o zabezpieczenie ważnego i godziwego zawarcia małżeństwa, że w przypadku wiernego akatolika zaświadczenie o jego stanie wolnym, z którego wynika „brak przeszkód do zawarcia małżeństwa”, nie jest wystarczające. W ten sposób rzeczywiście, jeśli osoba wcześniej małżeństwa nie zawierała, wystarczy dokument, który ten fakt potwierdzi. Ale potwierdzi wprost i bezpośrednio. Tak, aby nie było wątpliwości, iż ów „stan wolny”, który się $\mathrm{w}$ tym dokumencie potwierdza, jest rozumiany $\mathrm{z}$ zachowaniem i w kontekście Bożej zasady nierozerwalności małżeństwa. Innymi słowy, że „stan wolny” jest równoznaczny z niezawieraniem wcześniej małżeństwa bądź ewentualnie ze śmiercią współmałżonka, czyli z uszanowaniem zasady nierozerwalności ${ }^{28}$. Ta bowiem, jak się okazuje, choć podkreślana jest również w dokumentach Kościołów i Wspólnot kościelnych niekatolickich, to jednak jej rozumienie znacznie odbiega od tego stosowanego w Kościele katolickim.

\section{Establishment the free state of the faithful Lutheran Church in Poland before their marriage in the Catholic Church}

\section{Summary}

Along with the Catholic Church study, a marriage contracted between the baptized in a valid way is a sacrament and for his reason neither human power nor any cause can dissolve it, only the death. While the practice of the Lutheran Church in Poland provides a different perception of the same fundamental rules. Lutheran Church accepts divorce granted by secular law and allows of successive marriage by the faithful in Church. The purpose of this article is analysis of the situation when the Lutheran faithful intends to contract a marriage with a Catholic party and in the Catholic Church.

\footnotetext{
${ }^{28}$ Por. U. Nowicka, Stwierdzenie stanu wolnego..., dz. cyt., s. 325.
} 